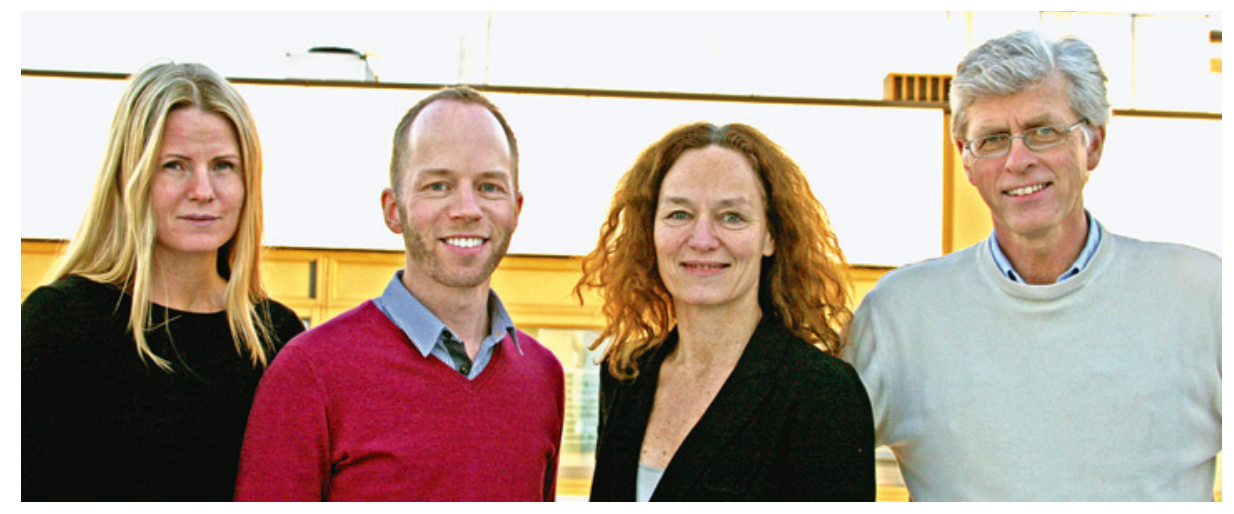

De fire norske medforfatterne: Fra venstre Christine Roth, Pål Surén, Camilla Stoltenberg og Per Magnus. Foto Torunn Gjerustad, Folkehelseinstituttet

\section{Kan folsyretilskudd forebygge autisme?}

Bruk av folsyretilskudd tidlig i graviditeten gir lavere risiko for autisme hos barnet.

Risikoen for nevralrørsdefekter hos barn reduseres når mor tar tilskudd av folsyre (vitamin $\mathrm{B}_{9}$ ) i tiden før og omkring befruktningen. Fra 1998 har Helsedirektoratet anbefalt kvinner som planlegger graviditet å ta et tilskudd av $400 \mu \mathrm{g}$ folsyre daglig fra én måned før starten av svangerskapet og til slutten av første trimester. Nå har norske forskere publisert en studie som tyder på at folsyretilskudd i tidlig graviditet også kan forebygge autisme hos barn (1).

Studien er basert på The Autism Birth Cohort Study (ABC-studien), en delstudie om autisme i den norske mor-og-barnundersøkelsen (MoBa-studien). Studiepopulasjonen omfattet over 85000 deltakere født i perioden 2002-08. Av disse hadde 270 fått diagnostisert en autismespekterforstyrrelse, enten barneautisme (klassisk autisme; $\mathrm{n}=114$ ), Aspergers syndrom $(n=56)$ eller atypisk eller uspesifisert autisme $(\mathrm{n}=100)$. For mødre som hadde brukt folsyre fra fire uker før til åtte uker etter start av graviditeten var risikoen for barneautisme hos avkommet $0,10 \%$, mot $0,21 \%$ for mødre som ikke hadde brukt folsyre i dette tidsrommet. Logistisk regresjonsanalyse ga en oddsratio på 0,61 (95\% KI 0,41-0,90) for barneautisme hos barn av kvinner som hadde brukt folsyre, tilsvarende en risikoreduksjon på 39\%. Analysen var justert for mors utdanningsnivå, mors paritet og barnets fødselsår. Bruk av folsyre etter uke 8 hadde ikke innvirkning på risikoen.

- Det var ingen assosiasjon mellom folsyrebruk og risiko for atypisk eller uspesifisert autisme. For Aspergers syndrom var antallet tilfeller for lavt til å gi tilstrekkelig statistisk styrke. Det var ingen assosiasjon mellom bruk av tran eller omega-3-tilskudd og risiko for barneautisme, til tross for at bruk av slike tilskudd var forbundet med de samme karakteristika hos mødrene som bruk av folsyretilskudd, forteller Pål Surén.

- Resultatene gir ytterligere støtte til anbefalingene om bruk av folsyretilskudd hos gravide og understreker betydningen av å begynne tidlig, helst før starten av svangerskapet, sier Surén.

\section{Forskergruppen}

ABC-studien drives av Folkehelseinstituttet i samarbeid med Columbia University i New York. Studien er finansiert av National Institute of Neurological Disorders and Stroke i USA. ABC-studien identifiserer barn med autismediagnoser i MoBa-prosjektet gjennom spørreskjemabasert screening ved tre års alder, henvisninger fra foreldre og helsepersonell og koblinger til Norsk pasientregister. Alle barn med en mulig autismediagnose er blitt invitert til en heldags klinisk undersøkelse ved Nic Waals Institutt i Oslo for å få bekreftet eller avkreftet diagnosen. I tidsrommet 2005-12 ble over 1000 barn undersøkt.

Artikkelens førsteforfatter, Pål Surén, er lege og doktorgradsstipendiat ved Folkehelseinstituttet. Hans doktorgradsprosjekt er finansiert gjennom Norges forskningsråd. Sisteforfatteren, Camilla Stoltenberg, er direktør for Folkehelseinstituttet og prosjektleder for ABC-studien i Norge. De andre norske medforfatterne har alle deltatt i gjennomføringen av MoBa-studien og ABC-studien. Samarbeidet med Columbia University har pågått siden 2001.

\section{Hanne Støre Valeur}

hanne.store.valeur@legeforeningen.no Tidsskriftet

\section{Litteratur}

1. Surén P, Roth $C$, Bresnahan M et al. Association between maternal use of folic acid supplements and risk of autism spectrum disorders in children. JAMA 2013; 309: 570-7.
Ordforklaringer

Folsyre og folat: Folsyre er den syntetisk fremstilte formen av folat (vitamin $B_{q}$ ). I vanlig kost finnes folat i bladgrønnsaker, bønner, linser, erter, egg, gjær og lever. Folat er kofaktor i syntese og metylering av DNA.

Logistisk regresjonsanalyse: Statistisk analyse hvor den den naturlige logaritmen for odds av utfallsvariabelen (i vårt tilfelle autisme) modelleres som en lineær funksjon av eksponeringsvariabelen (i vårt tilfelle bruk av folsyre). Modellen beregner relativ risiko i form av en oddsratio, dvs. odds hos de eksponerte (folsyrebrukere) delt på odds hos de ueksponerte (de som ikke brukte folsyre).

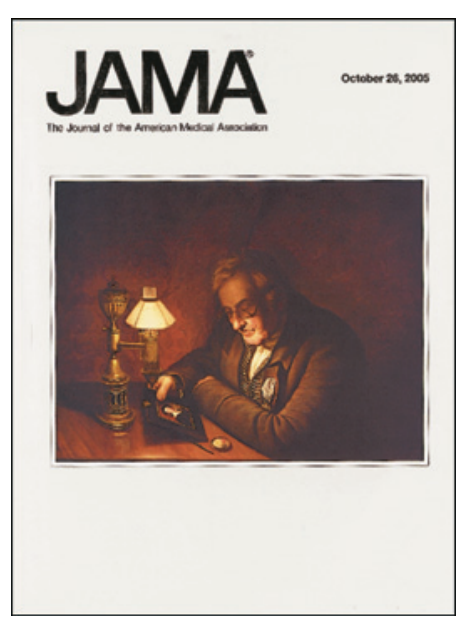

Artikkelen ble publisert i februar 2013 i det anerkjente medisinske tidsskriftet JAMA (The Journal of American Medical Association) 